
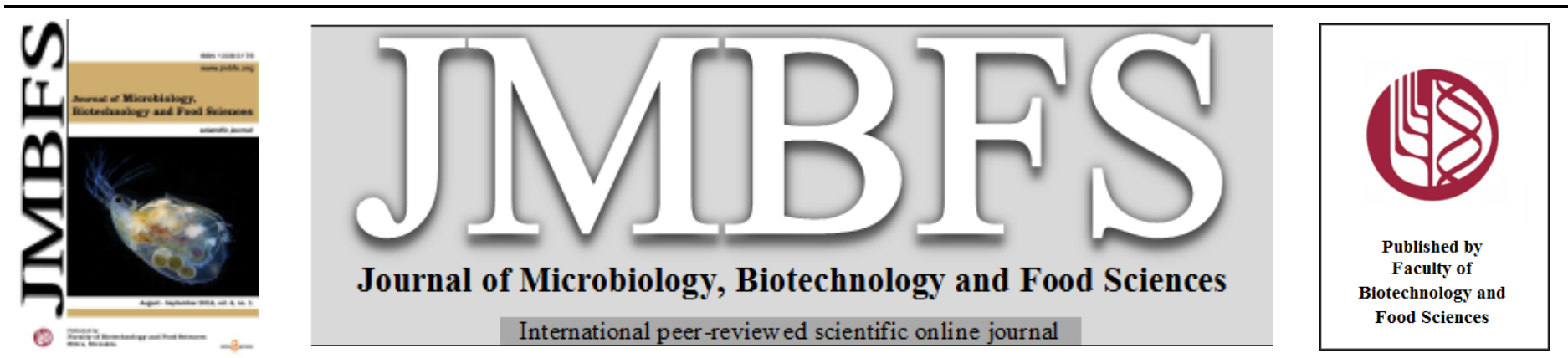

\title{
EFFECT OF LOW TEMPERATURE STORAGE ON THE THERAPEUTIC PROPERTIES OF THE IMMOBILIZED ON ADSORBENTS AND FREE CELLS OF SACCHAROMYCES BOULARDII
}

\author{
Igor P. Vysekantsev, Olga M. Babinets, Valentyna F. Martsenyuk*, Nikolay V. Repin, Igor F. Kovalenko
}

Address(es):

Institute for Problems of Cryobiology and Cryomedicine of the National Academy of Sciences of Ukraine 23 Pereyaslavskaya str., Kharkov 61016, Ukraine. Tel. +380573733126 .

*Corresponding author: martsenyuk@ukr.net

doi: 10.15414/jmbfs.2016.6.1.707-712

\section{ARTICLE INFO}

Received 1. 3. 2016

Revised 1.4. 2016

Accepted 11. 4. 2016

Published 1. 8. 2016

Regular article open $\partial$ ACcess

\begin{abstract}
Probiotic S. boulardii cells were immobilized on adsorbents "Sorbex" (activated carbon pellets) and "SCMS-1" (granules of aluminum dioxide with deposited film of activated carbon). The experimental probiotics were the "carrier-cells" systems, wherein on the carrier surface different amounts of yeast cells were absorbed. The safety of the "carrier-cells" systems was assessed on the number of macrocolonies formed by certain systems. During freezing down to low temperatures bigger number of immobilized cells if compared to free cells in the cell suspensions has been shown to dye. The safety of the complexes during freezing is affected by cooling mode and preserving medium composition. Experimental intestinal dysbiosis was induced in mice by oral administration of ampicillin and metronidazole. There has been found a longer persistence of yeast cells and higher levels of Bifidobacterium spp., Lactobacilus spp. bacteria in the colon mucin of the mice treated with immobilized S. boulardii. In the groups of animals treated with free cells and the mixtures of free cells with adsorbents, the terms of persistence of yeast cells and the recovery rates of Bifidobacterium spp., Lactobacilus spp. in colon mucin were lower. Storage for one year at $-80^{\circ} \mathrm{C},-196^{\circ} \mathrm{C}$ did not affect therapeutic properties of immobilized and free S. boulardii cells.
\end{abstract}

Keywords: Dysbiosis, probiotics, adsorbents, immobilization, low temperatures

\section{INTRODUCTION}

The "intestinal dysbiosis" term is considered as a symptom, testifying to quantitative and/or qualitative disorders in indigenous parietal intestinal microflora (Vorobyov et al., 1998). Here the dysbiosis is defined as more general notion, indicating a microbiological imbalance in the body. Intestinal dysbiosis is an aggravating factor in clinical pathology of various origins and the functioning disorders of different organs and systems (Tkachenko and Suvorov, 2009). The range of therapeutic measures to correct the dysbiotic changes in the gut includes pathogenetic treatment of the main disease, if necessary it also comprises a selective contamination of pathogenic and opportunistic microorganisms, restoring indigenous parietal intestinal microflora (Ardatskaya, 2008; Tokareva, 2011).

To correct the indigenous microflora there are applied various probiotic products: probiotics, prebiotics, synbiotics, metabiotics, probiotic dietary supplements (Bondarenko, 2012; Guarner et al., 2012). A number of randomized controlled trials and meta-analyzes of the experts of the Cochrane Collaboration shows that with the help of probiotic drugs a specific therapeutic or prophylactic effect in many pathologies can be achieved. A positive effect of probiotics was reported in the recommendations and communications of the FAO, WHO, WGO (Hempel $\boldsymbol{e t}$ al., 2012; Andreeva,2006; Floch et al., 2011; Floch, 2014; Probiotics,2012; Kailasapathy, 2002).

However, in some cases, no clinical effect of using the probiotics has been found. Many researchers believe that negative results when using probiotics are associated either with the death of probiotic microorganisms while passing through the natural protective gastrointestinal barriers or with biological incompatibility of the administered probiotic cells and patient's intestinal indigenous flora (Darmov et al., 2011). To increase the effectiveness of probiotic drugs there are designed the new formulations of those, namely the immobilized probiotics. The immobilized probiotics in microcapsules and gel carrier (Ding and Shah, 2009; Chen et al., 2007) have become more widespread. The studies on immobilization of probiotics on the carriers are poor.

The research aim was to study the effect of immobilized on adsorbents probiotic Saccharomyces boulardii, stored at low temperatures, on recovery of parietal microflora of Bifidobacterium spp., Lactobacilus spp. in the animals with experimental intestinal dysbiosis.

\section{MATERIALS AND METHODS}

\section{Research object}

The study was performed with Saccharomyces boulardii (S.boulardii) yeast species. Yeasts were isolated from the commercial drug "Enterol" ("Biocodex", France). Yeasts were grown on Sabouraud agar medium (Polyak et al., 2008) for $48 \mathrm{hrs}$ at a temperature of $30 \pm 2^{\circ} \mathrm{C}$. For further manipulations the cells were washed-out from the medium surface with $0.14 \mathrm{M} \mathrm{NaCl}$ solution.

\section{Immobilization}

The adsorbents "Sorbex" ("Ecosorb", Ukraine) and "SCMS-1" ("Novosibirskfarm", Russia) were experimentally selected as the carriers. Adsorbent "Sorbex" represents the granules of activated carbon, "SCMS-1" adsorbent is aluminum dioxide granules, coated with the activated charcoal film. Both of them have the developed meso- and macroporous structures. Yeast cells were immobilized on the carriers as described (Vysekantsev $\boldsymbol{e t}$ al., 2011). Into a $500 \mathrm{ml}$ flask there was added $200 \mathrm{ml}$ of cell suspension in $0.14 \mathrm{M} \mathrm{NaCl}$ solution with a concentration of $5 \cdot 10^{7}$ cells $/ \mathrm{ml}$. To the suspension there was added $1 \mathrm{~g}$ adsorbent. The flask was shaken for $30-60 \mathrm{~min}$ at a temperature of $0 \div 2{ }^{\circ} \mathrm{C}$. Free and non-immobilized $S$. boulardii cells served as the control.

\section{Freezing}

Before freezing the preparations of free and immobilized cells were pelleted by centrifugation and re-suspended in 5\% sucrose solution. Free cell suspension and supernatant of the "carrier-cells" systems were introduced into "Corning" cryovials ("Corning Incorporated", USA) with a $1.8 \mathrm{ml}$ handling volume. Part of the samples was cooled with a «Cryoson» programmable freezer for bioobjects (Germany) down to $-40^{\circ} \mathrm{C}$ with $1{ }^{\circ} \mathrm{C} / \mathrm{min}$ cooling rate, and then immersed into liquid nitrogen. The second part of the samples was placed on the shelves of low- 
temperature chamber "Jouan VX 380 " (France) with a temperature of $-80^{\circ} \mathrm{C}$. The samples were stored for a year at -196 and $(-80 \pm 4)^{\circ} \mathrm{C}$ respectively. The samples were thawed in a $30^{\circ} \mathrm{C}$ water bath

\section{Survival examination}

The viability of free cells was examined by Koch dish method (Lusta and Fichte, 1990) on the colony formation of Sabouraud agar. To test the effect of low temperature storage on the immobilized cell preparations we have used the term "preservation rate", i.e. the number of macrocolonies forming the individua "carrier-cells" systems. The preservation rate of the systems was examined by our own method (Martsenyuk et al.,2012). The need of this method applying and its layout stages could be found in «Results and discussion» section.

\section{Scanning electron microscopy}

Scanning electron microscopy (SEM) was performed with a scanning electron microscope REMMA 101 A («Selmi», Ukraine). The preparations for electron microscopy were fixed in $2.5 \%$ glutaraldehyde solution with $0.1 \mathrm{M} \mathrm{Na}$ cacodylate buffer, were dehydrated in ethyl alcohol. After dehydration the preparations were silver sprayed.

\section{Luminescent microscopy}

For fluorescence microscopy there was used a confocal laser scanning microscope LSM 510 META («Carl Zeiss», Germany). Dead cells were propidium iodide (PI) stained («Sigma-Aldrich», USA) as described (Dang, 2011). PI concentration in aliquots was increased from 3 up to $5 \mu \mathrm{g} / \mathrm{ml}$.

Therapy of experimental dysbiosis with immobilized Saccharomyces boulardii

The experiments were performed in 7-8 months-old white random-bred mice weighing of 18-20 g. All the manipulations were carried out in accordance with General Principles of Experiments in Animals (European, 1986). The animals were etherized for anesthesia. To simulate an intestinal dysbiosis the animals were orally administered using a gastric tube with $5 \mathrm{mg}$ ampicillin ("Arterium", Ukraine) and $2 \mathrm{mg}$ metronidazole ("Unique Pharmaceutical Laboratories", India) for 3 days. Within $48 \mathrm{hrs}$ after administration of ampicillin and metronidazole to the animals there was started the treatment with the preparations of free $S$ boulardii cells, mixtures of free and immobilized cells. The treatment lasted 12 days. Probiotics and adsorbents were administered once a day. The daily dose of free cells was $1.6 \cdot 10^{4}$ cells. Taking into account the safety of the systems of immobilized cells after low temperature storage the dose was increased twice. To days 5, 12 of dysbiosis therapy and 5,10 days later the treatment in the animals a colon mucin was sampled, in mucin there was examined the content of the number of Bifidobacterium and Lactobacillus bacteria (Ivanov et al., 2002) as well as of Saccharomyces boulardii yeasts. To isolate the yeasts serial mucin dilutions were plated on Sabouraud agar medium supplemented with chloramphenicol ("Arterium", Ukraine), at a final concentration of $0.05 \mathrm{~g} / \mathrm{l}$ (Polyak et al., 2008). Mucin preparations for light microscopy were Gram and Giemsa-Romanovsky stained (Korolyuk and Sboychakov, 2002). For additional fixation of sorbent granules the surface of preparations was agar gel coated on a phosphate buffer solution with $\mathrm{pH} 7.2$ - 7.4 (Morozov, 1999). Mucin preparations were examined using "Zeiss Primo Star" microscope (Germany) with the "Axio Vision 4" software.

\section{Statistical analysis of the results}

For statistical analysis of the findings the software package SPSS 17.0 («IBM», USA) was used. Statistical error threshold was set at $5 \%$.

\section{RESULTS AND DISCUSSION}

\section{Preservation rate of the "carrier-cell" systems after freezing and storage}

The first step was to study the post-thaw safety of the "carrier-cells" systems. The authors of research papers and patents dealing with the immobilization of probiotics on the carrires, determined the preservation of probiotic drugs either on cumulative effect on the composition of luminal intestinal microflora of the animals with experimental dysbiosis, or on the number of macrocolonies of probiotics after seeding by Koch dish method (Lusta and Fichte, 1990). Both methods used do not objectively assess the safety of namely the "carrier-cells" systems. The first method is mediated one on biological effects of drugs. Second one provides the overestimated results. When using it the authors considered the macrocolonies, formed by the "carrier-cells" systems and free cells, which were not immobilized or desorbed from the carrier surface during rehydration or thawing.

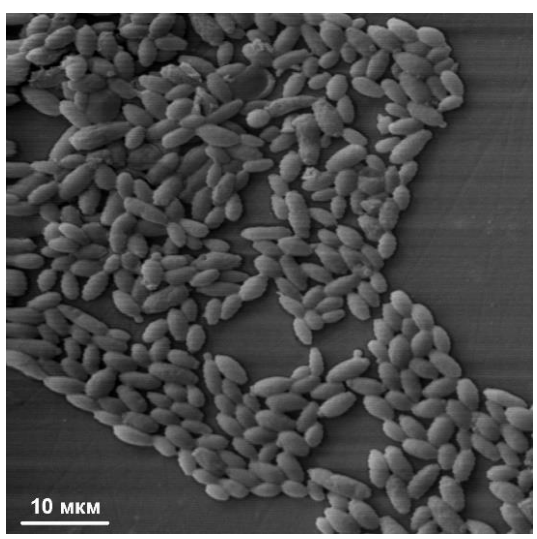

I-1

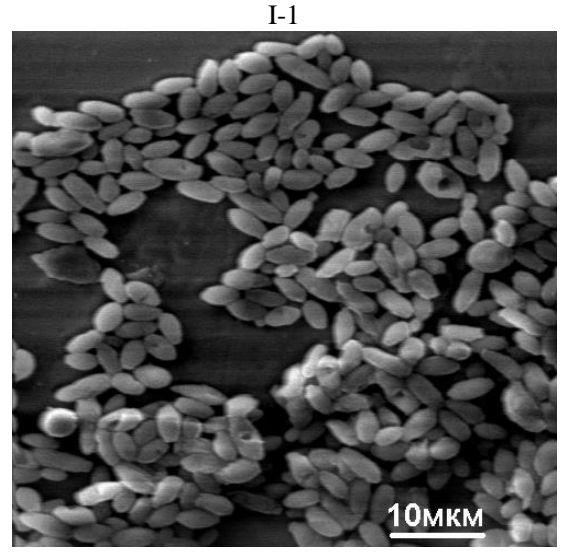

I-2

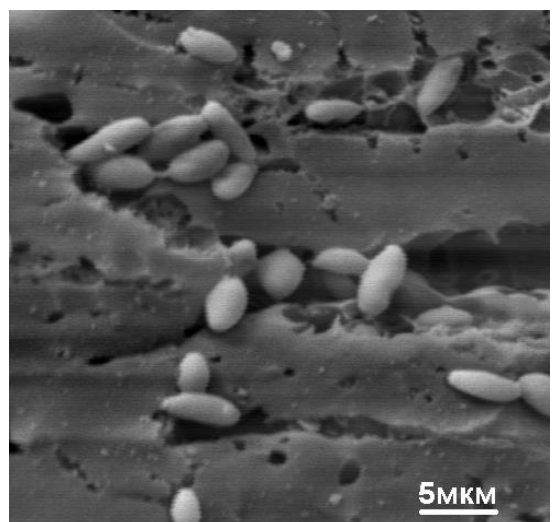

II-1

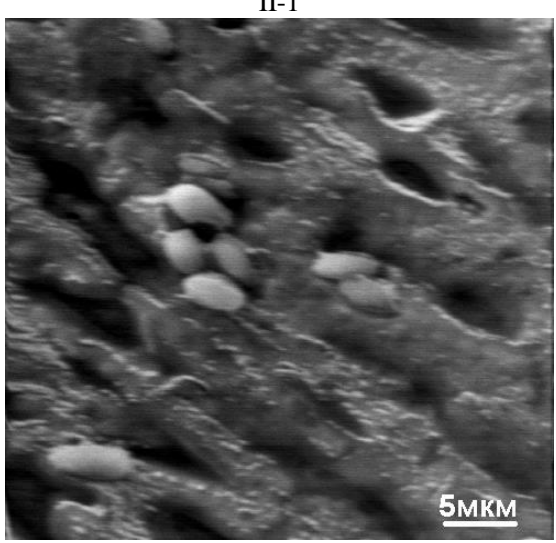

II-2

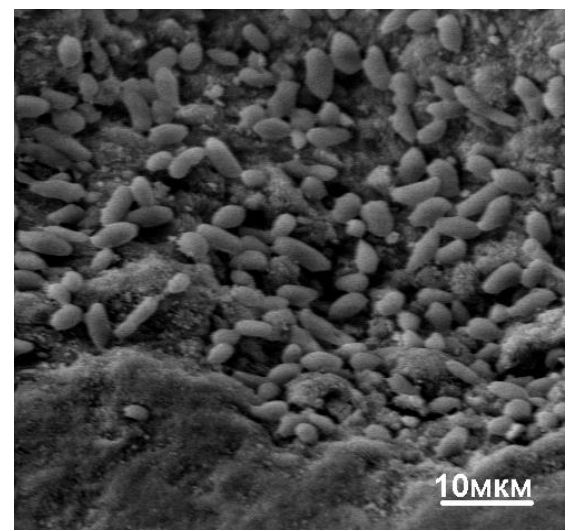

III-1

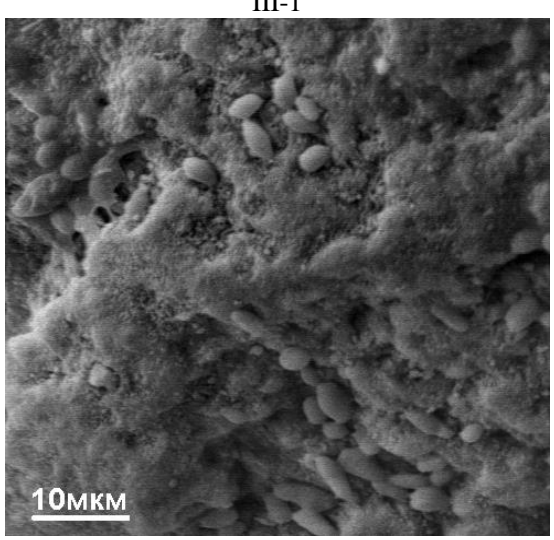

III-2

Figure 11 Electronograms of preparations of free (I) and immobilized on «Sorbex» (II) and «SCMS-1» (III) S.boulardii cells prior to (1) and after freezing down to $-196^{\circ} \mathrm{C}(2)$ 


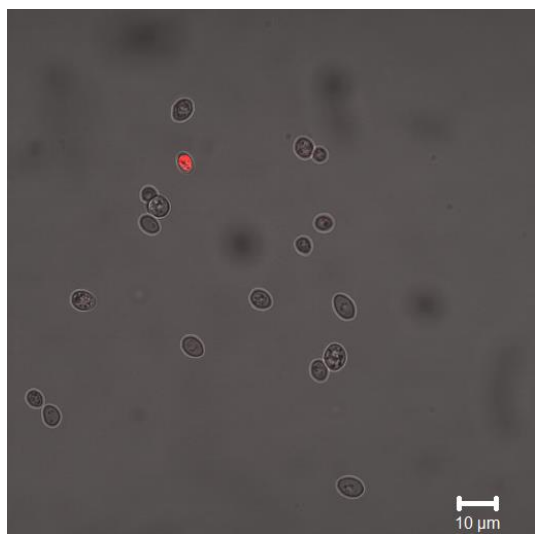

I-1

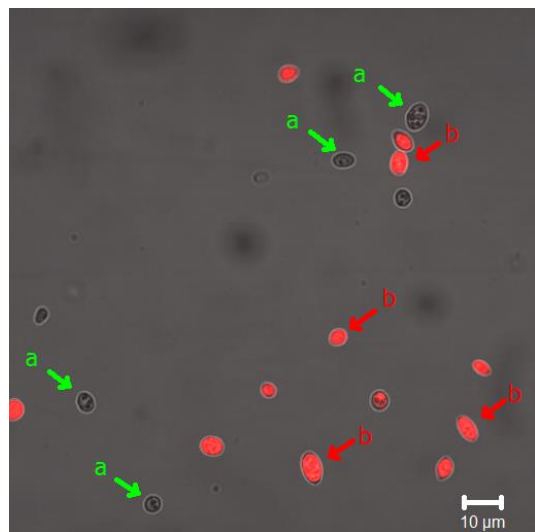

I-2

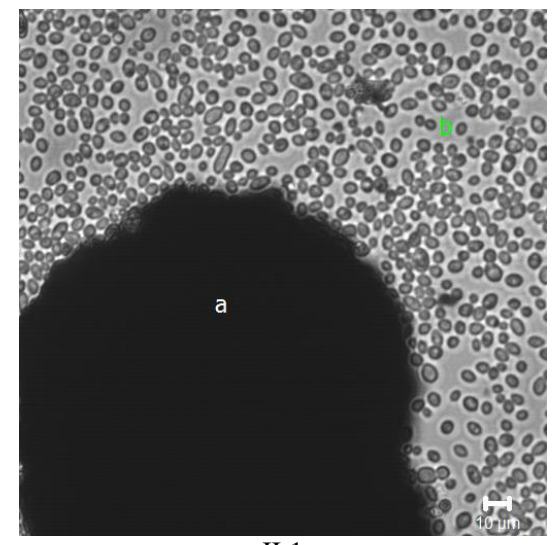

II-1

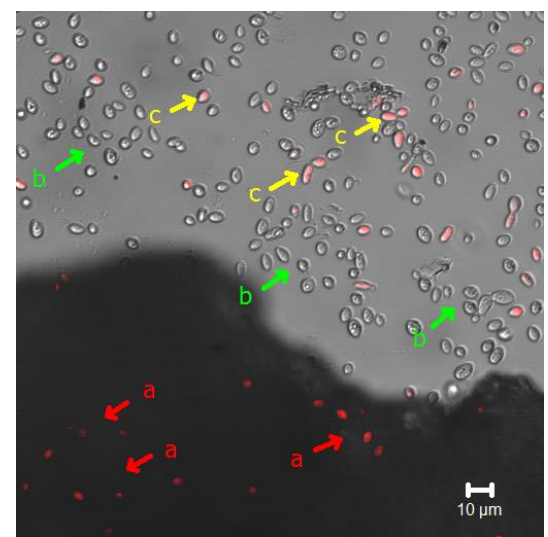

II-2

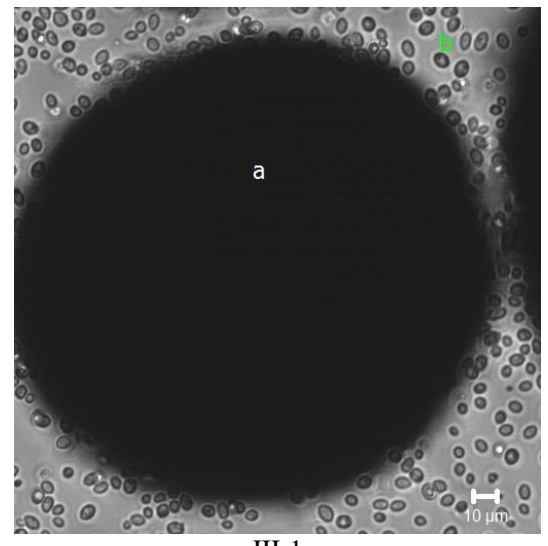

III-1

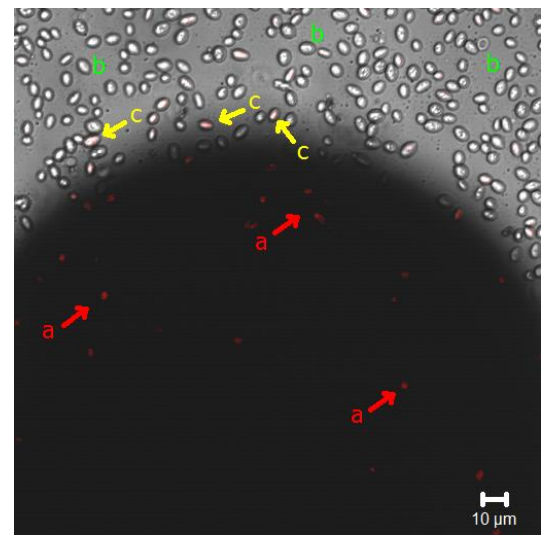

III-2

Figure 2 Confocal laser scanning microscopy of preparations of free (I) and immobilized on «Sorbex» (II) and «SCMS-1» (III) S.boulardii cells prior to (1) and after freezing down to $-196^{\circ} \mathrm{C}(2)$ : a - immobilized cells with PI inclusion; $\mathrm{b}$ - intact free cells; c - free cells with PI inclusion.

This analysis was confirmed by our research results for the preparations of immobilized $S$. boulardii cells using SEM and confocal fluorescence microscopy. In the photomicrographs obtained by the SEM, a portion of the yeast cells adhered directly to the carrier surface and the part of the cells penetrated into various depths of the carrier material macropores (Fig.1) are seen. The amount of cells in various sites of carriers differs. By outward appearances it is impossible to distinguish living and dead cells. The photomicrographs obtained by confocal fluorescence microscopy show that around "carrier-cells" systems there are free and non-immobilized cells. Among free and immobilized on the carriers' surface cells there are the ones with preserved outer structure, but with the PI inclusion (Fig.2). The number of cells with PI inclusion in different samples varies.

We have developed a method of accounting the macrocolonies formed only by the "carrier-cells" systems separated from free cells (Martsenyuk et al.,2012). In accordance with this method, the suspension of the immobilized cells is placed into a centrifuge tube with prefabricated membrane. Membrane wells allow only free cells. The tube is centrifuged, then the "carrier-cells" systems are shaken from a membrane into the tube with a certain volume of $0.2 \%$ agar. Consecutive serial dilutions in $0.2 \%$ agar solution are performed. From the serial dilutions the suspension of the complexes by $1 \mathrm{ml}$ is placed into Petri dishes and poured with agar growth medium (2\% agar). After solidification of agar medium the Petri dishes are cultured in an incubator and then the number of macrocolonies formed by the complexes is counted. The preservation rate for the systems is expressed by the number of colony forming units (CFU) per $1 \mathrm{ml}$ supernatant or $1 \mathrm{~g}$ adsorbent.

After storage of free and immobilized $S$. boulardii cells for 1 year the following results were obtained. At $-80^{\circ} \mathrm{C}$ free cells did not die for 6 months. In 12 months, the number of viable cells decreased from 7.7 down to $7.0 \mathrm{lg}$ CFU/ $\mathrm{ml}$ (Fig.3). At $-196^{\circ} \mathrm{C}$ using the aforementioned cooling regimen free cells did not die during a year.
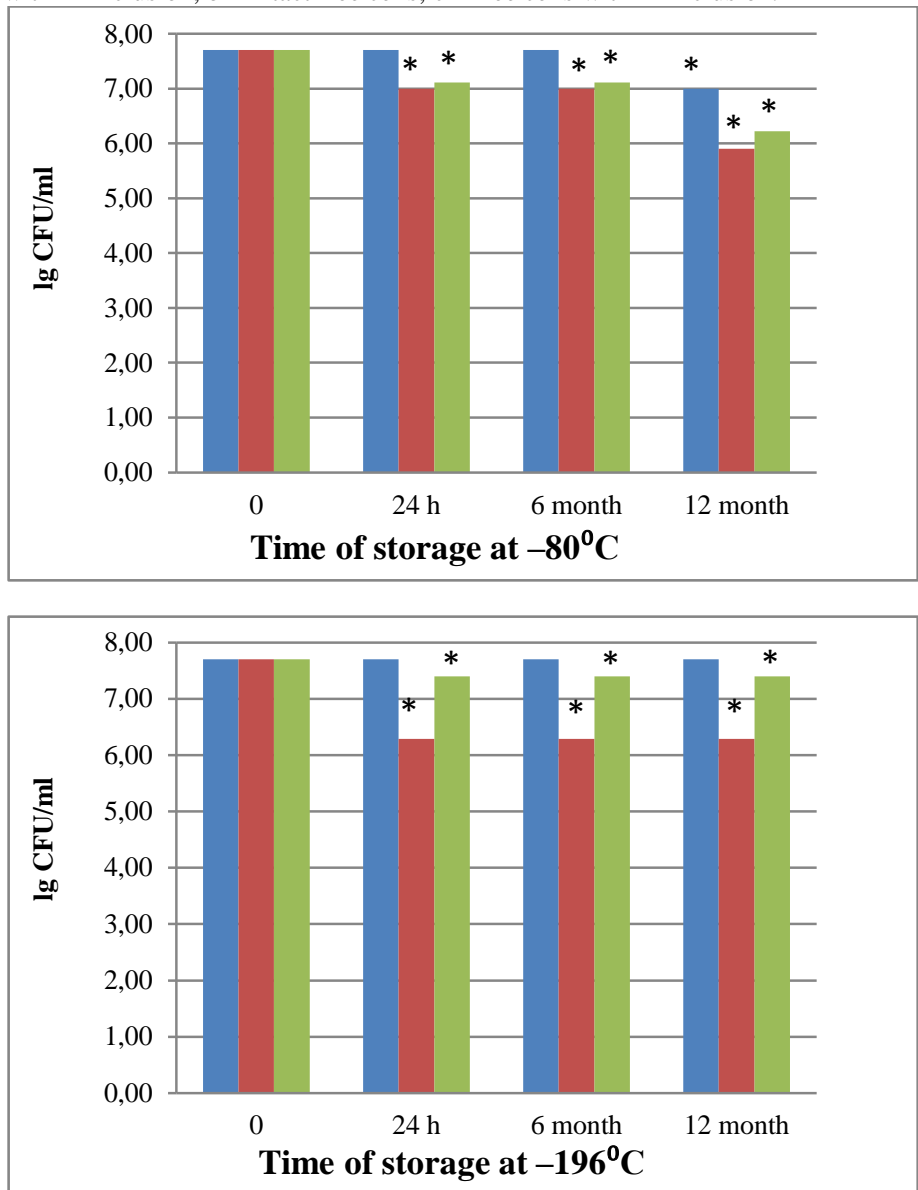

free cells $\mid$ cell systems immobilized on "SCMS-1" = cell systems immobilized on "Sorbex"

Figure 3 Preservation rate of free $S$. boulardii cells and "carrier-cells" systems after storage at $-80^{\circ}$ and $-196^{\circ} \mathrm{C}$. $*$ - statically significant differences between initial control and experiment. 
At $-80^{\circ} \mathrm{C}$ the number of systems of the cells immobilized on adsorbent "Sorbex" decreased through day from 7.7 to $7.11 \mathrm{lg}$ CFU/ml and remained at this level for 6 months. In 12 months, the safety of the systems has decreased to $6.22 \mathrm{lg}$ CFU/ml. Number of the systems of the cells immobilized on "SCMS -1" adsorbent in $24 \mathrm{hrs}$ also reduced from 7.7 down to $7.0 \mathrm{lg} \mathrm{CFU} / \mathrm{ml}$, remained at this level for 6 months, and in 12 months decreased to $5.9 \mathrm{lg} \mathrm{CFU} / \mathrm{ml}$.

After freezing down to $-196^{\circ} \mathrm{C}$ the number of the systems with "Sorbex" adsorbent decreased from 7.7 down to $7.4 \mathrm{lg} \mathrm{CFU} / \mathrm{ml}$, that with adsorben "SCMS-1" reduced from 7.7 to $6.29 \mathrm{lg} \mathrm{CFU} / \mathrm{ml}$. During storage at $-196^{\circ} \mathrm{C}$ for a year no extra death was observed.

\section{Therapy of experimental dysbiosis with immobilized Saccharomyces boulardii}

After dysbiosis induction in all the groups of animals there were noted the symptoms of intestinal dysbiosis: polifekalia, alternating diarrhea and constipation, change in stool consistency, reduction in body weight by $(3.5 \pm 0.5)$. In $48 \mathrm{hrs}$ after the last administration of chemodrugs the content of Bifidobacterium spp. in colon mucin decreased from (7.6 \pm 0.5$) \mathrm{lg}$ CFU/g down to $(2.1 \pm 0.4) \mathrm{lg} \mathrm{CFU} / \mathrm{g}$. Content of Lactobacillus spp. in mucin decreased from $(8.0 \pm 0.4) \mathrm{lg} \mathrm{CFU} / \mathrm{g}$ to $(2.4 \pm 0.5) \mathrm{lg} \mathrm{CFU} / \mathrm{g}$. Saccharomyces spp. yeasts were absent in mucin before and after dysbiosis induction.

In groups of the animals treated with native and stored for a year at $-80,-196^{\circ} \mathrm{C}$ free $S$. boulardii cells and the mixtures of free cells with adsorbents (groups 4-9) to day 5 of treatment in the colon parietal mucin the $S$. boulardii concentration was from $(3.7 \pm 0.3)$ to $(4.1 \pm 0.3) \mathrm{lg}$ CFU/g. To day 12 of treatment in mucin of the animals of these groups there were found from (3.9 \pm 0.3$)$ to (4.4 \pm 0.3$) \mathrm{lg}$ CFU/g of yeast cells. In 5 days after the treatment the concentration of $S$. boulardii in mucin made from $(0.5 \pm 0.02)$ to $(0.9 \pm 0.02) \mathrm{lg} \mathrm{CFU} / \mathrm{g}$. In 10 days after the treatment there were no yeast cells in mucin of the animals of groups 1-9. In groups of the animals treated with immobilized on adsorbents $S$. boulardii cells (group 10-15), the concentration of yeast cells in mucin to day 5 of treatment was $(6.0 \pm 0.5)$ to $(6.7 \pm 0.5) \mathrm{lg} \mathrm{CFU} / \mathrm{g}$ at day 12 of treatment from $(6.5 \pm 0.4)$ to $(6.8 \pm 0.4) \mathrm{lg}$ CFU/g. In 5 days after the treatment the concentration of yeast cells in mucin of the animals of these groups ranged from $(5.9 \pm 0.46)$ to $(6.2 \pm 0.35) \mathrm{lg}$ $\mathrm{CFU} / \mathrm{g}$ and in 10 days it was of $(2.8 \pm 0.4)$ to $(3.1 \pm 0.4) \mathrm{lg} \mathrm{CFU} / \mathrm{g}$.

Storage for one year at $-80,-196^{\circ} \mathrm{C}$ did not affect the ability of $S$. boulardii to persist in the colon mucin of the mice with experimental dysbiosis.

In all the groups of $S$. boulardii treated animals there was noted an increase in the Bifidobacterium spp., Lactobacilus spp. populations. In the mucin of the animals treated with free $S$. boulardii cells (groups 1-3), to day 12 of treatment the amount of Bifidobacterium spp., Lactobacilus spp. increased to $(3.3 \pm 0.4)-$ $(3.5 \pm 0.5) \mathrm{lg}$ CFU/g, 10 days after the end of treatment it was up to $(4.3 \pm 0.3)$ $(4.5 \pm 0.5) \mathrm{lg} \mathrm{CFU} / \mathrm{g}$ (Table 1$)$. In mucin of the animals treated with a mixture of free $S$. boulardii cells with adsorbents (groups 4-9) the number of Bifidobacterium spp. increased up to $(3.8 \pm 0.3)-(3.9 \pm 0.4)$ to day 12 and up to $(4.9 \pm 0.3)-(5.0 \pm 0.5) \mathrm{lg} \mathrm{CFU} / \mathrm{g}$ in 10 days later the treatment. In mucin of the animals treated with the preparations of immobilized $S$. boulardii cells (groups 10-15), the amount of Bifidobacterium spp. in mucin to day 12 of treatment was $(4.1 \pm 0.4)-(4.3 \pm 0.4)$, and 10 days later the end of treatment this was $(5.3 \pm 0.3)-$ (5.5 \pm 0.4$) \lg \mathrm{CFU} / \mathrm{g}$.

The number of Lactobacilus spp. in mucin of the animals treated with free $S$. boulardii cells, increased to day 12 of treatment to $(4.1 \pm 0.3)-(4.3 \pm 0.3) \mathrm{lg}$ $\mathrm{CFU} / \mathrm{g}$, in 10 days after treatment it was up to $(4.8 \pm 0.4)-(4.9 \pm 0.5) \mathrm{lg} \mathrm{CFU} / \mathrm{g}$ When applying the mixtures of $S$. boulardii cells with enterosorbents the number of Lactobacillus spp. to day 12 of treatment increased up to $(4.5 \pm 0.4)-(4.6 \pm 0.4)$ and 10 days after the treatment it was up to $(5.2 \pm 0.3)-(5.4 \pm 0.3) \mathrm{lg} \mathrm{CFU} / \mathrm{g}$. In mucin of the animals treated with immobilized $S$. boulardii cells, the amount of Lactobacillus spp. in mucin to day 12 of treatment was $(4.9 \pm 0.4)-(5.1 \pm 0.4)$, and 10 days later the treatment ceasing it was $(5.9 \pm 0.3)-(6.2 \pm 0.5) \mathrm{lg} \mathrm{CFU} / \mathrm{g}$. Storage for one year at -80 and $-196^{\circ} \mathrm{C}$ did not affect the ability of free and immobilized $S$. boulardii cells to contribute to a rise in Bifidobacterium spp. and Lactobacilus spp. populations in colon mucin.

Table 1 Content of Bifidobacterium spp. and Lactobacillus spp. in large intestine parietal mucin of mice with chemotherapeutic intestinal dysbiosis after introduction of free and immobilized yeast cells and adsorbents

\begin{tabular}{|c|c|c|c|c|c|c|c|c|}
\hline \multirow[b]{3}{*}{$\begin{array}{l}\text { Groups of animals (introduced } \\
\text { preparations) }\end{array}$} & \multicolumn{8}{|c|}{ Number of $\lg \mathrm{CFU} / \Gamma, \overline{\mathrm{X}} \pm \mathrm{S} \overline{\mathrm{x}}$} \\
\hline & \multicolumn{4}{|c|}{ Bifidobacterium spp. } & \multicolumn{4}{|c|}{ Lactobacillus spp. } \\
\hline & $\begin{array}{l}\text { Prior to } \\
\text { dysbiosis } \\
\text { induction }\end{array}$ & $\begin{array}{l}\text { In } 48 \text { hrs after } \\
\text { dysbiosis } \\
\text { induction (first } \\
24 \text { hrs of } \\
\text { observation) }\end{array}$ & $\begin{array}{l}\text { Day } 12 \text { of the } \\
\text { receiving } \\
\text { S.boulardii } \\
\text { preparation } \\
\text { (observation } \\
\text { day 12) }\end{array}$ & $\begin{array}{l}\text { In } 10 \text { days after } \\
\text { terminating the } \\
\text { receiving of } \\
\text { S.boulardii } \\
\text { preparations } \\
\text { (observation } \\
\text { day } 22 \text { ) }\end{array}$ & $\begin{array}{l}\text { Prior to } \\
\text { dysbiosis } \\
\text { induction }\end{array}$ & $\begin{array}{l}\text { In } 48 \text { hrs after } \\
\text { dysbiosis } \\
\text { induction } \\
\text { (first } 24 \text { hrs } \\
\text { of } \\
\text { observation) }\end{array}$ & $\begin{array}{l}\text { Day } 12 \text { of the } \\
\text { receiving } \\
\text { S.boulardii } \\
\text { preparation } \\
\text { (observation } \\
\text { day 12) }\end{array}$ & $\begin{array}{c}\text { In } 10 \text { days } \\
\text { after } \\
\text { terminating } \\
\text { the receiving } \\
\text { of } S . \text { boulardii } \\
\text { preparations } \\
\text { (observation } \\
\text { day } 22 \text { ) }\end{array}$ \\
\hline Animals with no treatment & $7.6 \pm 0.5$ & $2.1 \pm 0.4$ & $2.8 \pm 0.3$ & $3.6 \pm 0.4^{*}$ & $8.0 \pm 0.4$ & $2.4 \pm 0.5$ & $2.3 \pm 0.3$ & $3.0 \pm 0.4^{*}$ \\
\hline 1. Free S.boulardii cells & & & $3.5 \pm 0.5$ & $4.3 \pm 0.4^{*}$ & & & $4.2 \pm 0.4$ & $4.8 \pm 0.4^{*}$ \\
\hline $\begin{array}{l}\text { 2. Free S.boulardii cells stored at } \\
-80^{\circ} \mathrm{C}\end{array}$ & & & $3.3 \pm 0.4$ & $4.3 \pm 0.3^{*}$ & & & $4.1 \pm 0.4$ & $4.8 \pm 0.4^{*}$ \\
\hline $\begin{array}{l}\text { 3. Free S.boulardii cells stored at } \\
-196^{\circ} \mathrm{C}\end{array}$ & & & $3.3 \pm 0.5$ & $4.5 \pm 0.5^{*}$ & & & $4.3 \pm 0.3$ & $4.9 \pm 0.5^{*}$ \\
\hline $\begin{array}{l}\text { 4. Free S.boulardii cells + } \\
\text { «SCMS-1» }\end{array}$ & & & $3.8 \pm 0.4$ & $4.9 \pm 0.3^{*}$ & & & $4.5 \pm 0.4$ & $5.2 \pm 0.3^{*}$ \\
\hline $\begin{array}{l}\text { 5. Free S.boulardii cells + } \\
\text { «Sorbex» }\end{array}$ & & & $3.8 \pm 0.5$ & $4.9 \pm 0.4^{*}$ & & & $4.6 \pm 0.4$ & $5.3 \pm 0.3 *$ \\
\hline $\begin{array}{l}\text { 6. Free S.boulardii cells stored at } \\
-80^{\circ} \mathrm{C}+« \text { SCMS }-1 »\end{array}$ & & & $3.8 \pm 0.3$ & $4.9 \pm 0.3 *$ & & & $4.5 \pm 0.4$ & $5.4 \pm 0.4^{*}$ \\
\hline $\begin{array}{l}\text { 7. Free S.boulardii cells stored at } \\
-80^{\circ} \mathrm{C}+\text { }+ \text { Sorbex» }\end{array}$ & & & $3.8 \pm 0.3$ & $5.0 \pm 0.5^{*}$ & & & $4.5 \pm 0.3$ & $5.3 \pm 0.3 *$ \\
\hline $\begin{array}{l}\text { 8. Free S.boulardii cells stored - } \\
196^{\circ} \mathrm{C}+\text { «SCMS }-1 »\end{array}$ & & & $3.9 \pm 0.4$ & $4.9 \pm 0.3 *$ & & & $4.4 \pm 0.3$ & $5.3 \pm 04^{*}$ \\
\hline $\begin{array}{l}\text { 9. Free S.boulardii cells stored at } \\
-196^{\circ} \mathrm{C}+\langle\text { Sorbex» }\end{array}$ & & & $3.8 \pm 0.5$ & $4.9 \pm 0.4^{*}$ & & & $4.5 \pm 0.4$ & $5.4 \pm 0.3^{*}$ \\
\hline $\begin{array}{l}\text { 10. Immobilized on «SCMS-1» } \\
\text { S.boulardii cells }\end{array}$ & & & $4.1 \pm 0.4$ & $5.3 \pm 0.3^{*}$ & & & $4.9 \pm 0.4$ & $5.9 \pm 0.3^{*}$ \\
\hline $\begin{array}{l}\text { 11. Immobilized on «Sorbex» } \\
\text { S.boulardii cells }\end{array}$ & & & $4.2 \pm 0.3$ & $5.3 \pm 0.4^{*}$ & & & $4.9 \pm 0.4$ & $6.0 \pm 0.4^{*}$ \\
\hline $\begin{array}{l}\text { 12. Immobilized on }\langle\mathrm{SCMS}-1 » \\
\text { S.boulardii cells stored at }-80^{\circ} \mathrm{C}\end{array}$ & & & $4.3 \pm 0.4$ & $5.3 \pm 0.3^{*}$ & & & $4.9 \pm 0.4$ & $5.9 \pm 0.3^{*}$ \\
\hline $\begin{array}{l}\text { 13. Immobilized on «Sorbex»" } \\
\text { S.boulardii cells stored at }-80^{\circ} \mathrm{C}\end{array}$ & & & $4.3 \pm 0.4$ & $5.4 \pm 0.3 *$ & & & $4.5 \pm 0.3$ & $5.9 \pm 0.3^{*}$ \\
\hline $\begin{array}{l}\text { 14. Immobilized on «SCMS-1» } \\
\text { S.boulardii cells stored at }-196^{\circ} \mathrm{C}\end{array}$ & & & $4.1 \pm 0.5$ & $5.5 \pm 0.4^{*}$ & & & $5.0 \pm 0.4$ & $6.0 \pm 0.4^{*}$ \\
\hline $\begin{array}{l}\text { 15. Immobilized on «Sorbex» } \\
\text { S.boulardii cells stored at }-196^{\circ} \mathrm{C}\end{array}$ & & & $4.3 \pm 0.3$ & $5.4 \pm 0.3^{*}$ & & & $5.1 \pm 0.4$ & $6.2 \pm 0.5^{*}$ \\
\hline
\end{tabular}

Notes:

$*_{-}<0.05$ if compared with the content of bacteria (Bifidobacterium spp., Lactobacillus spp.) to day 12 of therapy and 10 days after terminating the receiving of S.boulardii preparations. 
During microscopy of the mucin preparations for the animals of all the groups to day 12 of treatment and 5,10 days after the treatment there was observed a rise in cell numbers of lactobacilli and bifidobacteria. Yeast cells in mucin of the animals of groups 1-9 was found to day 5 after the treatment end. In mucin of the animals of groups of $10-15$ treated with immobilized $S$. boulardii, to day 10 after the treatment end there were single free yeast cells and sorbent granules with no cells and with immobilized yeast cells.

In the groups of animals treated with immobilized probiotics to day 10 after the treatment end there were no clinical signs of intestinal dysbiosis. In other groups we observed some clinical manifestations of dysbiosis.

\section{DISCUSSION}

The findings indicate the research prospects on creating the probiotics, immobilized on sorbents. The developed method for assessing the preservation rate of the "carrier-cells" systems isolated from free cells allows to objectively estimate the safety of viable cells immobilized on the surface of the carrier particles. It was for the first time shown that the sensitivity of yeast cells immobilized on the carrier surface to damaging effects of freeze-thawing was higher if compared with free cells.

On the basis of generally accepted statements of the two-factor theory of cell cryoinjury (Mazur, 1967; Mazur et al., 1972), we assume the following reasons of higher death rate of the immobilized cells. A part of the surface of the immobilized cells closely contacts with the sorbent structures. The volume of the cells is herewith maintained, but the surface of cells through which the wate transport out of the cells at the stage of extracellular crystallization beyond the cells decreases. This strengthens an intracellular crystallization at the determined cooling rate. A second reason may be the damages of cell wall and cytoplasmic membrane on the boundary zone of the recorded on the cell surface carrier sites when reducing the cell volume during the transport of water out of them.

Due to the mentioned above to efficiently store the immobilized on adsorbents probiotics the choice of cooling mode and composition of preserving medium is crucial.

We used the conditions of low temperature storage of the immobilized on carbon containing adsorbents $S$. boulardii probiotic ensured the safety of therapeutic doses required for a growth stimulation of parietal populations of Bifidobacterium spp., Lactobacilus spp. in mice with experimental intestinal dysbiosis.

The results of the studies performed indicate that for efficient influence of probiotics their engraftment to a biofilm as part of gut microbiota is no mandatory. S.boulardii yeasts do not belong to microbiota of homoiotherma animals and are not able to adhere to an intestinal mucosa, but the clinical effect of their use is shown in several studies (Vandenplas et al., 2009). In our research we found that the introduction of free $S$. boulardii cells, the mixtures of adsorbents with free cells and those immobilized on adsorbent boosted the parietal populations of Bifidobacterium spp., Lactobacilus spp. This was due to the creation of the conditions ensuring the reproduction of indigenous bifidobacteria and lactobacilli which remained in the intestines of the animals after the dysbiosis induction in the concentrations below critical. An attention is drawn to the fact of more pronounced therapeutic effect of immobilized $S$. boulardii. The most likely explanation for this is as follows. The "carrier-cells" systems are cell conglomerates formed by co-adhesion. After an adhesion of the "carrier-cells" systems to an intestinal mucosa there are formed the microcolonies with the following structure: yeast cells - adsorbent granule - mucin - mucus epithelium. Herewith in the discrete sites of mucous with the mentioned microcolonies there is the number of yeast cells which is sufficient for stimulation of the reproduction of indigenous bifidobacteria and lactobacilli by their metabolites. This is supported by higher concentrations and longer persistence of yeast cells in mucin of the animals, which were injected with immobilized $S$. boulardii.

In the research we used the preparations of the "carrier-cells" systems, purified from free cells to study the effect of the systems per se. When developing the commercial drugs of probiotics immobilized on sorbents there is no need to purify them from free cells.

\section{CONCLUSION}

The idea of this study was to improve the ability of transient probiotic $S$ boulardii to stimulate the recovery of indigenous microflora (Bifidobacterium spp., Lactobacilus spp.) in the animals with a modeled chemotherapeutic intestinal dysbiosis. It was experimentally shown that the preparations obtained by immobilizing the yeast cells on the granules of carbon-containing adsorbents caused the pronounced therapeutic effect when treating an intestinal dysbiosis in animals if compared to the drugs of free cells and the mixtures of free cells with adsorbents. In the animals treated with immobilized probiotic S. boulardii, parietal Bifidobacterium spp., Lactobacilus spp. populations were restored more intensively and clinical manifestations of intestinal dysbiosis disappeared quickly. Low temperature storage $\left(-80,-196^{\circ} \mathrm{C}\right)$ provides a high preservation rate of free and immobilized on adsorbents $S$. boulardii cells. The results can be used to develop new probiotic drugs and design the drug delivery systems.

\section{REFERENCES}

ANDREEVA I.V. 2006. Potential for the Use of Probiotics in Clinical Medicine. Clinical Microbiology and Antimicrobial Chemotherapy, 8 (2), 151-172. [in Russian]

ARDATSKAYA, M.D. 2008. Intestinal dysbiosis :concept, diagnosis, treatment principles correction. Consiliummedicum, 10(8), 86-92. [in Russian]

BONDARENKO, V.M. 2012. Substantiation and tactics of administration of different forms of probiotic preparations in medical practice. Pharmateca, 246 (13), 77-87. [in Russian]

CHEN, M.J., CHEN, K.N., KUO, Y.T. 2007. Optimal thermotolerance of Bifidobacterium bifidum in gellan-alginate microparticles.Biotechnology and bioengineering, 98 (2), 411-419.

DANG, N.X., HINCHA, D.K. 2011. Identification of two hydrophilins that contribute to the desiccation and freezing tolerance of yeast (Saccharomyces $\begin{array}{llll}\text { cerevisiae }) \quad \text { cells. } & \text { Cryobiology, } & \text { 62(3), }\end{array}$ http://dx.doi.org/10.1016/j.cryobiol.2011.03.002

DARMOV, I.V., CHICHERIN, I.IU., POGOREL'SKIǏ, I.P., LUNDOVSKIKH, I.A.2011. Survival of probiotic microorganisms in the conditions in vitro imitating the process of human digestion. Eksp Klin Gastroenterol, (3), 6-11. [in Russian]

DING, W.K., SHAH, N.P. 2009. Effect of various encapsulating materials on the stability of probiotic bacteria. Journal of food science, 74 (2), 100-107. http://dx.doi.org/10.1111/j.1750-3841.2009.01067.x

European convention for the protection of vertebrate animals used for experimental and other scientific purposes: Council of Europe. 1986. Strasbourg, $1-53$.

FLOCH, M.H., WALKER, W.A., MADSEN, K., SANDERS, M.E., MACFARLANE, G.T., FLINT, H..J, DIELEMAN, L.A., RINGEL, Y. GUANDALINI ,S., KELLY, C.P., BRANDT, L.J. 2011. Recommendations for Probiotic Use-2011 Update . J Clin Gastroenterol, 45, Suppl, S168-S171. http://dx.doi.org/10.1097/mcg.0b013e318230928b

FLOCH, M.H. 2014. Recommendations for Probiotic Use in Humans - A 2014 Update. Pharmaceutical, 7(10), 999-1007. http://dx.doi.org/10.3390/ph7100999 GUARNER, F., KHAN, A.G., GARISCH, J., ELIAKIM, R., GANGL, A. THOMSON, A., KRABSHUIS, J., LEMAIR, T., KAUFMANN, P., DE PAULA, J.A., FEDORAK, R., SHANAHAN, F., SANDERS, M.E., SZAJEWSKA, H., RAMAKRISHNA, B.S., KARAKAN, T., KIM, N.; WORLD GASTROENTEROLOGY ORGANIZATION. 2012. World Gastroenterology Organisation Global Guidelines: probiotics and prebiotics October 2011. J Clin Gastroenterol, $46 \quad$ (6), 468-481. http://dx.doi.org/10.1097/mcg.0b013e3182549092

HEMPEL, S., NEWBERRY, S.J., MAHER, A.R. WANG, Z, MILES, J.N, SHANMAN, R., JOHNSEN, B., SHEKELLE, P.G. 2012. Probiotics for the prevention and treatment of antibiotic-associated diarrhea: a systematic review and meta-analysis, JAMA. 307(18),1959-1969. http://dx.doi.org/10.1001/jama.2012.3507

IVANOV, V.P., BOYTSOV, A.G., KOVALENKO, A.D., LASTOVKA, O.N., NILOVA, E.A. 2002. Improvement of the methods to diagnose large intestine dysbiosis: information letter: St-Petersburg: State Center of Epidemiological Surveillance, $1-31$

[in Russian]

KAILASAPATHY K. 2002. Microencapsulation of Probiotic Bacteria: Technology and potential applications. Curr. Issues intest. Microbiology, 3(2),39-48.

KOROLYUK, A.M., SBOYCHAKOV, V.B., editors. Medical microbiology.Part 1. 2002. St.-Petersburg: Meditsyna, 267. [in Russian]

LUSTA, K.A., FICHTE, B.A. 1990. Methods for determining the viability ofmicroorganisms. Pushchino, 1-86. [in Russian]

Martsenyuk, V.F., Babinets, O.M., Vysekantsev, I.P., 2012. UA. Patent No.№72110, Kyiv: State Intellectual Property Service of Ukraine [in Ukrainian] MAZUR, P., LEIBO, S.P., CHU, E.H. 1972. A two-factor hypothesis of freezing injury. Evidence from Chinese hamster tissue-culture cells. Exp Cell Res.,71(2), 345-355.

MAZUR, P. 1967. Physical-chemical basis of injury from intracellular freezing in yeast, in Cellular injury and resistance in freezing organisms. Asahina E.Ed. Institute of Low Temp. Sci.,Sapporo,Japan,171-189.

Morozov I.A.1999. Problems of Helicobacter pylori morphologicaldiagnosis in the stomach. Russian Journal of Gastroenterology, (2), 46-48. [in Russian] POLYAK, M.S., SUKHAREVICH, M.E., SUKHAREVICH, V.I. 2008. Culture mediafor medical microbiology. St. Petersburg: ELBI-SPb, 1-352. [in Russian] Probiotics for GI Health in 2012: Issues and Updates: http://www.isapp.net/Portals/0/docs/News/merenstein\%20sanders\%20CME\%20P robiotics.pdf

TKACHENKO, E.I., SUVOROV, A.N., editors. Intestinal Dysbiosis. Guidelines for the Diagnosis and Treatment . 2009. A.N. Suvorov. St. Petersburg: InformMed,. 276 p. [in Russian] 
TOKAREVA, N. 2011. Correction and prevention of dysbacteriosis. Effective pharmacotherapy. Gastroenterology. 3.77-84. [in Russian]

VANDENPLAS Y., BRUNSER O., SZAJEWSKA H. 2009. Saccharomyces boulardii in childhood . Eur J Pediatr. 168(3), 253-265 http://dx.doi.org/10.1007/s00431-008-0879-7

VOROBYEV, A.A., ABRAMOV, N.A., BONDARENKO, V.M. SHENDEROV, B.A. 1997. Dysbioses as actual problem of medicine. Annals of the Russian Academy of medical Sciences, 3, 4-7. [in Russian]

VYSEKANTSEV, I.P., BABINETS, O.M., MARTSENYUK, V.P., SHATILOVA, L.E. 2011.Comparative study of adsorption of standard markers and Saccharomyces boulardii, Bifidobacterium bifidum probiotics on enterosorbents. Visnyk Problem Biologii i Meditsyny, Issue 1: 58-62 [in Russian] 